\title{
PERLINDUNGAN HUKUM BAGI KONSUMEN ATAS PENJUALAN PRODUK OBRAL ONLINE
}

\author{
Dewa Gede Widya Swastika, Anak Agung Sagung Laksmi Dewi \& Luh Putu Suryani \\ Fakultas Ilmu Hukum, Universitas Warmadewa, Denpasar-Bali, Indonesia \\ Dewagede@gmail.com, laksmidewi29@gmail.com \& putusuryani099@gmail.com
}

\begin{abstract}
Abstrak
Indonesia merupakan negara berkembang yang mana salah satu aspek yang sangat mempengaruhi perkembangannya adalah dibidang perekonomian, dalam hal ini meliputi bidang perdagangan. Adanya perdagangan bebas menyebabkan tidak sedikit diantara pelaku usaha melakukan persaingan yang tidak sehat, khususnya bagi produk yang diperdagangkan. Penelitian ini bertujuan menelaah perlindungan hukum bagi konsumen terhadap penjualan produk obral online tanpa disertai informasi yang jelas dan membahas pertanggungjawaban pelaku usaha terhadap konsumen yang mengalami kerugian akibat pembelian produk obral online. Penelitian normatif adalah tipe penelitian yang digunakan didalam penelitian ini dengan menggunakan pendekatan perundang-undangan. Dengan fenomena ini mustahil orang terlepas dari pengaruh bisnis dan sebagai konsekuensinya, masyarakat adalah konsumen yang menjadi sasaran para produsen. Hasil penelitian ini ditemukan bahwa konsumen yang mengalami kerugian akibat informasi yang kurang jelas dari jualan obral online dapat melaporkan perbuatan tidak menyenangkan tersebut dengan dasar hukum termuat dalam Undang-undang Nomor 8 Tahun 1999 tentang Perlindungan Konsumen. Penelitian ini diharapkan dapat meningkatkan kesadaran, pengetahuan, dan kemandirian konsumen untuk melindungi kepentingannya, yang pada akhirnya dapat menumbuhkan sikap pelaku usaha yang jujur dan bertanggung jawab, khususnya dalam hal penjualan produk melalui sosial media atau online.
\end{abstract}

Kata kunci: Bisnis, Konsumen, Perlindungan Hukum, Produk Obral Online.

\begin{abstract}
Indonesia is a developing country which one of the aspects that greatly influence its development is in the field of economy, in this case covering the field of trade. The existence of free trade is not little among businesses conducting unhealthy competition, especially for traded products. The purposes of this research are to examine the legal protections for the consumer of online sale products that contain unclear information about the products and to analyze the owner's responsibility to the consumers who get a loss because of the online sale products. Normative research is a type of research used in this study using a statutory approach. With this phenomenon it is impossible for people to be separated from the influence of business and as a consequence, society is the consumer who is the target of the producers. The results of this research found that consumers who get a loss due to unclear information from online sales can report these unpleasant acts on the legal basis contained in Law Number 8 of 1999 concerning Consumer Protection. This research hopes it could increase awareness, knowledge, and independence of consumers to protect their interests, which in turn can foster an honest and responsible attitude of business actors, especially in terms of selling products through social media or online.
\end{abstract}

Keywords: Business, Consumer, Legal Protection, Online Sale Products.

\section{PENDAHULUAN}

Indonesia merupakan negara berkembang dengan sektor perekonomiannya yang paling berpengaruh terhadap kemajuan negara. Dalam memajukan perekonomian pemerintah menyiapkan lapangan pekerjaan kepada semua masyarakat namun tidak semua bisa bekerja dipemerintahan karena berbagai alasan, salah satunya pendidikan minimal dan usia, semakin tua usia semakin tidak diterima seseorang untuk bekerja diperusahaan atau pemerintahan karena manusia memiliki fase produktif. Hal lain yang menyebabkan sulitnya mendapat pekerjaan adalah 
tidak sejalannya ertumbuhan rakyat Indonesia dengan pertumbuhan ekonomi (Pratama, Mahendrawati \& Ujianti, 2021). Namun, tidak semua masyarakat Indonesia menyerah dengan keadaan beberapa diantara membuka usaha untuk bisa melanjutkan kegiatan yang dapat menghasilkan sesuatu untuk menghidupi dirinya dan keluarganya.

Seiring berkembangnya teknologi dan kebutuhan masyarakat bisnis merupakan pekerjaan yang berjangka panjang dapat memajukan ekonomi keluarga dengan beberapa cara bisnis dapat dimulai bahkan tanpa menggunakan modal. Bahkan banyak orang yang dengan sengaja berhenti dari pekerjaannya untuk memulai bisnis karena dengan berbisnis secara online seseorang dapat mengatur dan melakukan pekerjaan sesuka hati sesuai dengan keadaan berbeda halnya jika melakukan pekerjaan kantoran maka seorang mau tidak mau datang tepat waktu dan mengerjakan pekerjaan yang telah terjadwalkan (Djakfar, 2012), dengan berkembangnya teknologi maka bukan dari sektor perekonomiannya saja yang berkembang melainkan dari segi kejahatannya juga. Salah satu kejahatan dibidang perekonomian adalah penipuan dan pemalsuan. Kecurangan beberapa pihak yang sengaja menjual dan memasarkan suatu produk tidak sesuai dengan kualitas. Namun kehati-hatian konsumen jarang berpengaruh terhadap produk yang dipasarkan dengan santainya pihak penjual meyakinkan konsumen untuk membeli suatu produk tanpa memikirkan resiko dan ijin makanan atau minuman yang dibeli.

Sifat konsumen yang mudah tergiur dengan harga yang lebih murah menjadi alasan utama penggunaan teknik ini, sehingga diharapkan dapat meningkatkan daya beli masyarakat. Penjualan produk secara obral ini dapat menguntungkan pihak pelaku usaha dan pihak pembeli atau konsumen. Dari pihak pelaku usaha, dengan adanya penjualan produk secara obral, maka konsumen akan tertarik untuk membeli produk tersebut, sehingga terjadi peningkatan omzet penjualan, yang juga berarti adanya peningkatan laba. Sedangkan dari pihak konsumen, dengan adanya penjualan secara obral, maka konsumen dapat membeli produk tersebut dengan harga yang relatif lebih murah daripada sebelum ada pemotongan harga.

Penjualan produk obral online biasanya membuat kontrak kerja yang merupakan bentuk perjanjian berdasarkan perjanjian antara pemilik produk yang biasanya sebelum terjadinya proses jual beli di mana persetujuan perpanjangan kontrak oleh masing-masing pihak yang terlibat adalah tanda resmi bahwa majikan bekerja pada penjual di perusahaannya dan untuk karyawan (tenaga kerja) secara resmi bekerja untuk perusahaan untuk jangka waktu terbatas atau tidak terbatas sesuai dengan semua yang dinyatakan dalam kontrak kerja (Manulang, 1988). Menurut Pasal 16202 KUHP, perjanjian kerja adalah hasil dari perjanjian antara pengusaha dan pekerja untuk membangun hubungan kerja, di mana karyawan majikan terikat satu sama lain selama periode tertentu untuk melakukan pekerjaan tertentu untuk mendapatkan upah sesuai konsepnya. Dengan adanya kontrak kerja ini, baik majikan maupun pekerja tidak dapat memberikan perintah dan melakukan pekerjaan sewenang-wenang, tetapi harus sesuai dengan ketentuan kontrak kerja. Setelah adanya kontrak kerja ini maka muncullah hubungan yang terbangun yakni hubungan industrial. Hubungan Industrial adalah sistem hubungan antara para pelaku produksi barang dan jasa yang terdiri dari unsur pengusaha, pekerja/buruh dan pemerintah (Kartasapoetra dkk, 1994)

Dewasa ini banyak para penjual produk obral online yang meski sudah mendapatkan penghasilan masih memiliki kekurangan dana untuk memenuhi kebutuhan hidupnya dan keluarganya. Berbagai alasan yang ada seperti apa yang dikerjakan tidak sesuai upah sampai tidak sesuai kemampuan namun tetap melakukan pekerjaan tersebut yang membuat pekerja tidak betah dalam bekerja. Semakin seseorang melakukan pekerjaan tidak dengan keikhlasan dan keinginan maka semakin berat dan susah pekerjaan yang dilakukan.

Banyaknya orang yang membutuhkan pekerjaan membuat persaingan ditempat kerja juga semakin ketat ditambah sedikitnya perusahaan yang membuka lowongan untuk para pekerja membuat banyak masyarakat yang menganggur sembari berharap adanya lowongan pekerjaan yang di buka. Para pekerja yang sudah mendapat pekerjaan harus melakukan pekerjaan sebaik mungkin dan tidak melanggar SOP yang berlaku supaya mempertahankan jabatannya dan meminimalisir terjadinya pemutusan hubungan kerja. Melihat peluang yang ada saat ini penjualan produk obral online menjadi sampingan tersendiri bagi beberapa orang tidak terkecuali para pekerja yang tidak lagi mendapatkan pekerjaan. Namun terkadang sebaik apapun pekerjaan yang 
dilakukan ada saja ketidakcocokan antar pedagang atau dengan suplayer produk herbal, suplayer harus banyak bersabar demi mempertahankan pekerjaan karena sulitnya saat ini mencari pekerjaan. Bagi pihak konsumen yang tidak sengaja dan timbul gejala yang merugikan maka dapat menuntut konpensaasi dari supleyer, namun jika secara sengaja mengetahui minuman tersebut tidak memiliki ijin edar namun tetap dikonsumsi maka kesalahan ada pada konsumen. Bagi penjual seharusnya sudah menyadari peraturan yang dibuat pemerintah yang bekerja sama dengan badan pengawas makanan dan minuman serta mengetahui sanksi dari perbuatannya.

Ada beberapa penelitian terdahulu terkait penelitian ini, Permatasari (2018) mengkaji tentang Perlindungan Hukum Bagi Konsumen atas Penjualan Produk Tas Obral Online. Hasil dari penelitian ini adalah konsumen tidak hanya mendapatkan kerugian karena adanya informasi yang tidak jelas tetapi konsumen juga tidak mendapatkan perlindung an nyata yang telah dijamin dalam UUPK dan tidak adanya bentuk pertanggungjawaban yang dilakukan oleh penjual dikarenakan ketidaktahuan konsumen terkait prinsip pertanggungjawaban didalam transaksi jual-beli online. Kemudian ada penelitian Noviani \& Darmawan (2019) meneliti tentang perlindungan hukum terhadap konsumen atas penjualan produk obral menggunakan prinsip loss leader (Harga Umpan). Tujuan penelitian dari Noviani \& Darmawan ini adalah menjelaskan pelaksanaan penerapan perlindungan konsumen terhadap penjualan produk obral secara loss leader, menjelaskan pelaksanaan tanggungjawab pelaku usaha atas kerugian konsumen dari penjualan produk obral. Dan penelitian yang relevan yang terakhir adalah perlindungan konsumen dengan ketidaksesuaian harga dalam promosi diskon secara online dengan harga sesungguhnya (Karim \& Gunarto, 2019). Penelitian tersebut bertujuan untuk mengetahui dan memahami hak - hak konsumen yang dilanggar dan bagaiamana tanggung jawab produsen atas promosi diskon yang diberikan. Dari penjelasan beberapa penelitian sebelumnya kemudian peneliti mencoba untuk meneliti perlindungan hukum bagi konsumen produk obral online, dimana penelitian ini berfokus untuk menelaah perlindungan hukum bagi konsumen terhadap penjualan produk obral online tanpa disertai informasi yang jelas dan membahas pertanggungjawaban pelaku usaha terhadap konsumen yang mengalami kerugian akibat pembelian produk obral online.

\section{METODE PENELITIAN}

Penelitian ini dilakukan dengan mencari data melalui buku ilmu hukum dan menghubungkan dengan permasalahan yang diangkat kemudian mengkaitkan dengan perundang-undangan yang berlaku saat ini. Dari segi hukum penelitian ini termasuk penelitian normatif. Penelitian normatif adalah penelitian yang diperoleh dari penjelasan secara detail dan sistematis dengan cara membedah aturan hukum (Susanti \& effendi, 2014). Dalam pengerjaannya peneliti mengumpulkan informasi dengan menelaah dan menganalisa buku-buku hukum yang didasari peraturan-peraturan hukum yang berlaku di Indonesia. Peneliti mengkaitkan dengan peraturan yang berlaku dan tidak menyimpang dari undang-undang dasar. Pendekatan penelitian dengan cara mengkaji, mencari dan memilah data dari berbagai hukum-hukum dan berpatokan pada undang-undang sebagai dasar penelitian penelitian. Penelitian ini bertujuan mencari informasi yang akurat dengan mempelajari gejala masyarakat untuk mendapatkan data yang sebenarbenarnya. Dengan demikian data dapat digabungkan dengan berbagai referensi buku hukum yang terkait dan menghasilkan penelitian yang tidak melenceng dari hukum positif. (Ahmad, 2008).

\section{HASIL DAN PEMBAHAN}

\section{Perlindungan Hukum Bagi Konsumen terhadap Penjualan Produk Obral Online Tanpa} Disertai Informasi yang Jelas

Dalam melakukan pekerjaan seseorang berhak mendapatkan kebebasan untuk berinovasi dan melakukan hal yang diinginkan namun sesuai dengan batasan yang ada, ada beberapa prinsip dalam melakukan pekerjaan:

1. Prinsip kebebasan merupakan prinsip dasar semua orang, teruntuk yang bekerja ataupun yang tidak bekerja. Segala aktivitas bebas dilakukan namun semua sesuai dengan etika dan tidak merugikan pihak lain. Dalam melakukan pekerjaan seseorang bebas mengajukan pendapat, 
menyuarakan ketidaksetujuan akan putusan yang dibuat, semua biasa terjadi karena dengan perbedaan pemikiran membuat suatu perusahaan semakin solit

2. Prinsip ketidaksetaraan, merupakan prinsip yang sudah terdoktrin pada beberapa orang khususnya dalam pekerjaan. Membeda-bedakan pergaulan sesuai dengan kasta atau materi. Hal seperti itu kadang membuat beberapa orang risih dan tidak jarang menjadi korban bully atau penindasan. Kedua prinsip ini saling berdampingan karena terjadi disetiap aktivitas yang dilakukan dan ada dilingkungan masing - masing orang.

Setiap hari terjadi dua hal yang saling berlawanan tersebut tinggal masing-masing individu yang bebas memilih prinsip mana yang digunakan dalam melakukan aktivitas seharihari termasuk dalam lingkungan sekitar. Perbedaan prinsip tersebut membuat negara Indonesia sampai saat ini belum maju karena masih banyaknya pihak yang memilih prinsip ketidaksetaraan yang secara tidak langsung melakukan perbuatan yang menguntungkan diri sendiri.

Berkaca pada konsep di Negara Republik Indonesia menganut keadilan sosial, kebanyakan masyarakat saat ini lebih cuek dengan keadilan sosial karena banyak yang lebih bertingkah laku tidak adil. Tidak adil disini berarti tidak mematuhi peraturan atau hukum positif yang berlaku. Hal itu juga terjadi didalam Kasus jual beli produk online, dimana para pelaku seolah orang yang buta akan hukum dan disatu sisi mengetahui peredaran penjualan produk online tanpa disertai informasi yang tidak jelas itu tidak diperbolehkan serta disisi lain banyaknya antusias masyarakat untuk membeli (Kartasapoetra, 1994). Berbicara soal perlindungan konsumen erat kaitannya dengan hak, bagaimana tidak jika seseorang tidak mendapatkan haknya maka hal tersebut adalah bentuk ketidakadilan. Namun hak seseorang didapat apabila sudah melaksanakan kewajibannya dan secara langsung mempertanggungjawabkan kewajiban yang dilaksanakannya. Ketika menyadari bahwa hak-haknya telah dilanggar oleh pelaku usaha maka pihak konsumenpun berhak mempertanyakan bahkan menggugat bila tidak sesuai dengan prinsip yang ada (Susanto, 2008)

Seseorang sebagai konsumen tentunya berhak mendapatkan perlindungan dari pemerintah, salah satu tindakan pemerintah dalam melindungi konsumen tentu dengan membuat undang-undang perlindungan konsumen. Sesuai dengan perundangan perlindungan komsumen, kontrak kerja adalah perjanjian antara pekerja dengan majikan atau pemberi kerja yang memuat kondisi kerja, hak dan kewajiban para pihak. Kontrak kerja berisi ketentuan yang berkaitan dengan hubungan kerja, yaitu hak dan kewajiban karyawan (karyawan) dan hak dan kewajiban pengusaha (pengusaha). Ketentuan yang dapat dimasukkan dalam kontrak kerja lain: jenis pekerjaan, durasi kontrak, jumlah upah bulanan, durasi waktu luang (cuti) dan jumlah upah selama cuti, jika sebagian besar dari untung, jika ada cara untuk menyediakan pensiun atau menawarkan jaminan untuk hari tua lainnya, bentuk upah lain dan di mana karyawan dikembalikan dengan biaya dari majikan.

Penjualan produk online merupakan penjualan yang praktis dan dengan teknologi yang ada saat ini membuat masyarakat lebih gampang untuk memperoleh barang yang diinginan namun dalam berbelanja konsumen biasanya lalai atau tidak memperdulikan informasi yang tertera pada produk online yang dijual dan lebih menggunakan kemasan yang dibungkus secara menarik tanpa mempertimbangkan resiko yang akan diterima jika menggunakan sesuatu tanpa menadapatkan informasi yang jelas. Belanja online dewasa ini sudah seperti menjadi budaya untuk masyarakat timur yang meniru gaya masyarakat barat, namun di Indonesia membeli produk online sering berlebihan seperti seorang yang kecanduan. Kebanyakan yang membeli produk online ini adalah remaja yang dimana masih belum stabil dalam mengelola emosi, hal ini biasanya yang membuat para remaja mengabaikan anjuran atau informasi yang tertera pada suatu barang tersebut dan lebih mengedepankan tampilan suatu produk. Promo gratis ongkir juga adalah salah satu alasan yang menyebabkan seseorang dapat dengan mudahnya berbelanja online.

Sisi positif pembelian produk online adalah dapat menambah pemasukan negara, namun kita harus tetap bisa mengontrol pengeluaran dan memperhitungakan keadaan ekonomi dengan tujuan untuk memprioritaskan keperluan saat ini dan tidak menambah terjadinya angka kemiskinan. Pemerintah membuat peraturan bagi siapa saja yang memperjualbelikan produknya secara online 
wajib menyertakan informasi yang pasti agar tidak terjadi salah pemakaian yang membuat suatu produk merugikan konsumen.

\section{Pertanggungjawaban Pelaku Usaha terhadap Konsumen yang Mengalami Kerugian Akibat Pembelian Produk Obral Online}

Peraturan pemerintah terkait penjualan produk atau barang online yang tanpa memiliki informasi yang jelas sudah diterapkan namun masih banyak pihak yang dengan sengaja dan mengetahui konsekuensi dari perbuatannya masih memasarkan produk atau barang online dan banyak diantara masyarakat yang dengan senang hati membeli bahkan mengkonsumsi produk online tersebut tanpa memikirkan efek sampingnya. Hanya sedikit diantara masyarakat yang menyadari sanksi dari pada hukum positif di Indonesia (Soekanto, 1987).

Sanksi sendiri memiliki makna dan arti yang berbeda - beda dan sesuai peraturan yang di buat pemerintah. Penjabaran sanksi sebagai berikut:

1. Sanksi Pidana

Merupakan sanksi yang paling memberikan efek jera diantara sanksi lainnya, hal ini ditunjukan dari hukuman yang diterima bervariasi seperti menetap dipenjara dan melakukan kegiatan yang ada dirumah tahanan selain itu memberikan citra buruk kepada diri sendiri dan keluarga karena kedapatan melakukan perbuatan pidana.

2. Sanksi Perdata

Sanksi perdata biasanya melibatkan konflik antar konsumen dan penjual produk online yang tidak memberikan informasi jelas pada produk yang diperjualbelikan hal ini membuat ketegangan antar pihak yang menjurus ke meja hijau atau persidangan guna mengetahui siapa yang harus disalahkan dan mengganti rugi setiap prestasi.

3. Sanksi Administratif

Sanksi ini berkaitan dengan pemerintahan semisal pelanggaran lalu lintas, akibat daripada tidak membayar pajak dan masih banyak lagi pelanggaran yang membuat seseorang harus mengganti rugi pada negara karena kelalaiannya.

Dalam mempertanggungjawabkan kesalahan yang sampai membuat terjadinya kerugian konsumen pihak penjual produk online yang tanpa memiliki keterangan yang jelas sesuai dengan pengaturan pemerintah tentang perlindungan konsumen, pihak penjual harus mengganti kerugian yang diderita konsumen dan jika dalam kasus kerugian konsumen sampai ada terjadinya meninggal dunia maka dikenakan sanksi pidana dan ganti rugi atas kerugian tersebut. Pemerintah sudah menghimau berkali-kali tentang pemberian informasi yang jelas terhadap produk yang dipasarkan melalui media sosial guna meminimalisasikan kerugian konsumen yang berujung ganti rugi serta sanksi lain yang nantinya memberatkan pihak penjual. Terlebih terjadinya kesalahan yang dilakukan pihak penjual yang sampai membuat kerugian konsumen dapat membuat nama produk dan nama sendiri menjadi tercemar dan dapat mengurangi permintaan pasar terkait produk tersebut.

\section{KESIMPULAN DAN SARAN}

\section{Kesimpulan}

Setelah peneliti memaparkan penjelasan mengenai hasil dan membahasnya, kemudian peneliti menarik beberapa kesimpulan berdasarkan penjelasan diatas, yaitu sebagai berikut:

1. Pasal 15 Undang Undang Nomor 8 Tahun 1999 tentang Perlindungan Konsumen, dapat dijadikan suatu pedoman bagi konsumen dalam bertransaksi khususnya jual beli online. Salah satu bentuk upaya perlindungan bagi konsumen yang tercantum dalam undangundang tersebut adalah adanya penyebutan secara tegas hak-hak konsumen. Dengan adanya hak konsumen dapat memberikan kenyaman dalam melakukan pembelian suatu produk.

2. Pertanggungjawaban pelaku usaha terhadap konsumen yang mengalami kerugian akibat pembelian produk online dengan ganti rugi atas kerusakan, pencemaran, dan/atau kerugian konsumen akibat mengkonsumsi barang dan/atau jasa yang dihasilkan atau diperdagangkan, bahwa ganti rugi tersebut dapat dilakukan dalam bentuk pengembalian 
uang atau penggantian barang dan/atau jasa yang sejenis atau setara nilainya, atau perawatan kesehatan dan/atau pemberian santunan yang sesuai dengan ketentuan peraturan perundang-undangan yang berlaku. Ganti rugi harus telah diberikan dalam jangka waktu 7 (tujuh) hari terhitung sejak tanggal transaksi.

\section{Saran}

Melalui penelitian ini peneliti ingin menyampaikan beberapa saran yang kiranya dapat membantu dalam menguatkan peraturan pemerintah dan memberikan pengetahuan kepada pelaku belanja online agar lebih memperhatikan produk yang akan dibeli, yaitu sebagai berikut:

1. Dengan makin maraknya penjualan produk online dengan informasi yang tidak jelas dan mengakibatkan penyesatan pada konsumen, maka sudah seharusnya diberlakukan suatu peraturan perundang-undangan yang secara tegas dan jelas mengatur tentang iklan. Dan juga, perlu kiranya dibentuk suatu lembaga tersendiri yang berperan aktif dalam pengawasan, sehingga kepentingan konsumen dapat tetap terlindungi dari perbuatan pelaku usaha dalam iklan yang menyesatkan tersebut.

2. Dengan masih minimnya pengetahuan masyarakat konsumen mengenai hak dan kewajibannya, maka perlu adanya sosialisasi lebih lanjut mengenai berbagai ketentuan dalam Undang-undang Nomor 8 Tahun 1999 tentang Perlindungan Konsumen. Sehingga diharapkan dapat meningkatkan kesadaran, pengetahuan, dan kemandirian konsumen untuk melindungi kepentingannya, yang pada akhirnya dapat menumbuhkan sikap pelaku usaha yang jujur dan bertanggung jawab, khususnya dalam hal penjualan produk melalui sosial media atau online.

\section{DAFTAR PUSTAKA}

Ahmad, B. (2008). Metode Penelitian. pustaka Setia, Bandung.

Djakfar, M. (2012). Etika bisnis: Menangkap Spririt Ajaran Langit dan Pesan Moral Ajaran Bumi. Penebar Plus, Jakarta.

Karim, F \& Gunarto, H. (2019). Perlindungan Konsumen Dengan Ketidaksesuaian Harga Dalam Promosi Diskon Secara Online Dengan Harga Sesungguhnya. Konferensi Ilmiah Mahasiswa Unissula (KIMU).

Kartasapoetra, G. dkk (1994). Hukum Peburuhan di Indonesia Berlandaskan Pancasila. Sinar Grafika, Jakarta.

Manulang, S. H. (1998). Pokok-pokok Hukum Ketenagakerjaandi Indonesia. PT Rineka Cipta, Jakarta.

Noviani, S. \& Darmawan. (2019). perlindungan hukum terhadap konsumen atas penjualan produk obral menggunakan prinsip Loss Leader (Harga Umpan). Jurnal Hukum Ilmiah Mahasiswa, Vol.3(4).

Permatasari, A. N. (2018). Perlindungan Hukum Bagi Konsumen atas Penjualan Produk Tas Obral Online. Program Studi Ilmu Hukum Fakultas Hukum. Universitas Negeri Semarang.

Pratama, A. A. N. B. K., Mahendrawati, N. L. M., \& Ujianti, N. M. P. (2021). Perlindungan Hukum bagi Konsumen pada Bank Beku Operasi. Jurnal Interpretasi Hukum, Vol.2(1).

Soekanto, S. (1987). Sosiologi Hukum dalam Masyarakat. Rajawali, Jakarta.

Susanto, H. (2008). Hak-hak konsumen jika dirugikan. Visimedia, Jakarta.

Susanti, Dyah, O. \& Efendi, A. (2014). Penelitian Hukum (Legal Research). Sinar Grafika, Jakarta. 